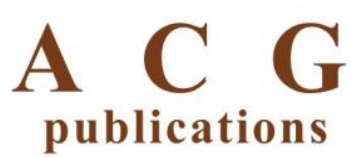

Rec. Nat. Prod. 14:1 (2020) 42-47

records of natural

products

\title{
Histone Deacetylase Inhibitor Induced Lipase Inhibitors from Endophytic Phomopsis sp. 0391
}

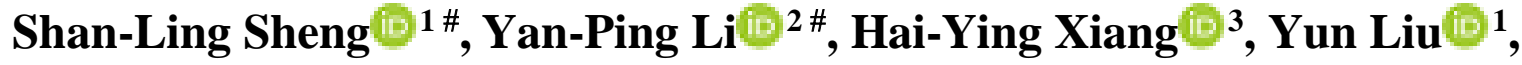 Yu-Dan Wang ${ }^{*}$ *, Ling-Peng Kong ${ }^{4}$, Gang Du ${ }^{1}$, Qiu-Fen Hu 1 , Yi-Jian Chen ${ }^{1}$ and Wei-Guang Wang ${ }^{1 *}$}

\author{
${ }^{1}$ Key Laboratory of Chemistry in Ethnic Medicinal Resources, State Ethnic Affairs Commission and \\ Ministry of Education, Yunnan Minzu University, Kunming 650031, China \\ ${ }^{2}$ School of Chinese Pharmacy, Yunnan University of Traditional Chinese Medicine, Kunming 650500, \\ China \\ ${ }^{3}$ Key Laboratory of Tobacco Chemistry of Yunnan Province, China Tobacco Yunnan Industrial Co, \\ Ltd., Kunming 650231, China \\ ${ }^{4}$ Yunnan Institute of Food Safety, Kunming University of Science and Technology, Kunming, 650500, \\ China
}

(Received May 04, 2019; Revised May 22, 2019; Accepted May 23, 2019)

\begin{abstract}
Seven compounds including a new one named as 13-angeloyloxy-diplosporin (1) were isolated from the endophytic Phomopsis sp. 0391 cultivated in the presence of a histone deacetylase inhibitor. All of these isolates were evaluated for lipase suppressive activities and we firstly found that compounds cytosporone B (5) and dothiorelone A (6) displayed significant lipase inhibited activities compared to the positive control (Orlistat, $\mathrm{IC}_{50}=43 \mu \mathrm{g} / \mathrm{mL}$ ) with the $\mathrm{IC}_{50}$ values at 115 and $275 \mu \mathrm{g} / \mathrm{mL}$, respectively.
\end{abstract}

Keywords: Phomopsis; endophytic fungi; chemical epigenetics approach; lipase inhibitor; NMR. (C) 2019 ACG Publications. All rights reserved.

\section{Introduction}

Filamentous fungi is a rich source of biologically active natural product metabolites with wideranging biological activity [1-5]. The genome sequencing studies showed that many fungi strains presence of many cryptic biosynthetic gene clusters encoding uncharacterized secondary metabolites [1]. While, such compounds are difficult to obtain under standard culture conditions because most of these biosynthetic gene clusters are silent and need to be active using different methods [6-7]. Chemical epigenetics approach is one of an effective technique for promoting the transcription of silent biosynthetic pathways involved in the fungi natural products discovery [8-11]. Asai and coauthors found that some endophytic fungi cultivated in the presence of $500 \mu \mathrm{M}$ suberoyl bishydroxamic acid (SBHA) (a histone deacetylase inhibitor) could promote some fungi to produce some novel natural products such as spiroindicumides A and B, mollipilins A-E, and chaetophenols A-F,

\footnotetext{
\# These authors contributed equally to this work

*Corresponding authors: Email : Yu-Dan Wang : sdlcwyd@163.com and Wei-Guang Wang: wwg@live.cn
} 
isolated from some different filamentous fungi [8]. In our research for finding bioactive natural products from endophytic fungi isolated from Traditional Chinese Medicine (TCM) [12-14], seven natural products including a new one have been isolated from the cultures of the fungus $P$. sp. 0391 endophytic to the stems of Paris polyphylla var. yunnanensis in the presence of a histone deacetylase inhibitor. (Figure 1). We found that the cultivation of $P$. sp. 0391 in the presence of $500 \mu \mathrm{M}$ SBHA significantly enhanced its secondary metabolite production, leading to the isolation of a new diplosporin derivative together with some other know ones. In this paper, we demonstrate that chemical epigenetic manipulation led to a substantial restructuring of secondary metabolite produced by an endophytic fungal isolate and the major compound's isolation, structure elucidation and lipase inhibited activities.

\section{Materials and Methods}

\subsection{General Experimental Procedures}

Optical rotations were measured with a JASCO P-1020 polarimeter. NMR spectra were recorded on Bruker AM-800 spectrometers. HRESIMS experiment was performed on a Bruker HCT/Esquire spectrometer and a Waters AutoSpec Premier P776 spectrometer. Column chromatography was performed with silica gel (200-300 mesh, Qingdao marine), RP-18 gel (40-63 $\mu \mathrm{m}$, YMC), and Sephadex LH-20 gel (40-70 $\mu \mathrm{m}$, GE Healthcare). Semipreparative HPLC was performed on a liquid chromatograph with a $9.4 \mathrm{~mm} \times 25 \mathrm{~cm}$ column (Agilent, ZORBAX SB-C18). Fractions were monitored by TLC, and compounds were visualized by heating silica gel plates sprayed with $10 \%$ $\mathrm{H}_{2} \mathrm{SO}_{4}$ in EtOH. All solvents including petroleum ether $\left(60-90^{\circ} \mathrm{C}\right)$ were distilled prior to use.

\subsection{Fungal Material}

The culture of $P$. sp. 0391 was isolated from the stems of Paris polyphylla var. yunnanensis collected from Kunming, Yunnan, People's Republic of China, in 2017. The isolate was identified based on sequence (GenBank Accession No. MK311351) analysis of the ITS region of the DNA. The fungal strain was cultured on slants of potato dextrose agar at $30{ }^{\circ} \mathrm{C}$ for 3 days. Agar plugs were cut into small pieces (about $0.5 \times 0.5 \times 0.5 \mathrm{~cm}^{3}$ ) under aseptic conditions, and 15 pieces were used to inoculate three Erlenmeyer flasks $(250 \mathrm{~mL})$, each containing $50 \mathrm{~mL}$ of media $(0.4 \%$ glucose, $1 \%$ malt extract, and $0.4 \%$ yeast extract); the final $\mathrm{pH}$ of the media was adjusted to 6.5 , and the flasks were sterilized by autoclave. Three flasks of the inoculated media were incubated at $30{ }^{\circ} \mathrm{C}$ on a rotary shaker at $170 \mathrm{rpm}$ for 5 days to prepare the seed culture. Fermentation was carried out in 50 Fernbach flasks $(500 \mathrm{~mL})$, each containing $200 \mathrm{~mL}$ of potato dextrose broth in the presence of $500 \mu \mathrm{M}$ SBHA incubated at $30{ }^{\circ} \mathrm{C}$ on a rotary shaker at $200 \mathrm{rpm}$ for 7 day.

\subsection{Fermentation, Isolation, and Purification}

The fermented material was extracted with EtOAc $(5 \times 10.0 \mathrm{~L})$, and the organic solvent was evaporated to dryness under vacuum to afford a crude extract $(5.6 \mathrm{~g})$. The crude extract was purified by $\mathrm{CC}$ (column chromatography on $\mathrm{SiO}_{2}$ with a petroleum ether-ethyl acetate gradient system 10:1, $5: 1,2: 1,1: 1,0: 1)$ to yield five main fractions, $F r .1-5$. Compound $4(3.8 \mathrm{mg})$ was mainly detected in Fr. 2 (petroleum ether-ethyl acetate, 5:1; $100 \mathrm{mg}$ ). Fr. 4 (petroleum ether-ethyl acetate, 1:1; $320 \mathrm{mg}$ ) was purified by semi-preparative HPLC $\left(3 \mathrm{~mL} / \mathrm{min}\right.$, detector UV $\left.230 \mathrm{~nm}, \mathrm{MeCN}-\mathrm{H}_{2} \mathrm{O}, 40: 60\right)$ to yield 2 (7.0 mg, $8.2 \mathrm{~min}), 3(4.6 \mathrm{mg}, 11.8 \mathrm{~min}), \mathbf{1}(17.8 \mathrm{mg}, 18.3 \mathrm{~min})$, and $\mathbf{5}$ (68 $\mathrm{mg}, 22.3 \mathrm{~min})$, respectively. Fr. $5(600 \mathrm{mg})$ was purified by $R P-18$ gel $\mathrm{CC}$ with $\mathrm{MeOH}-\mathrm{H}_{2} \mathrm{O}(30: 70,45: 55,60: 40$, 75:25, and 100:0) to yield Fr. 5.1-5.5. Fr. $5.3\left(90 \mathrm{mg}, \mathrm{MeOH}-\mathrm{H}_{2} \mathrm{O}, 60: 40\right)$ was purified by semipreparative HPLC $\left(3 \mathrm{~mL} / \mathrm{min}\right.$, detector UV $\left.230 \mathrm{~nm}, \mathrm{MeCN}-\mathrm{H}_{2} \mathrm{O}, 40: 60\right)$ to yield $6(11.1 \mathrm{mg}, 13.5$ $\mathrm{min})$ and 7 (18.3 $\mathrm{mg}, 13.9 \mathrm{~min})$, respectively. 


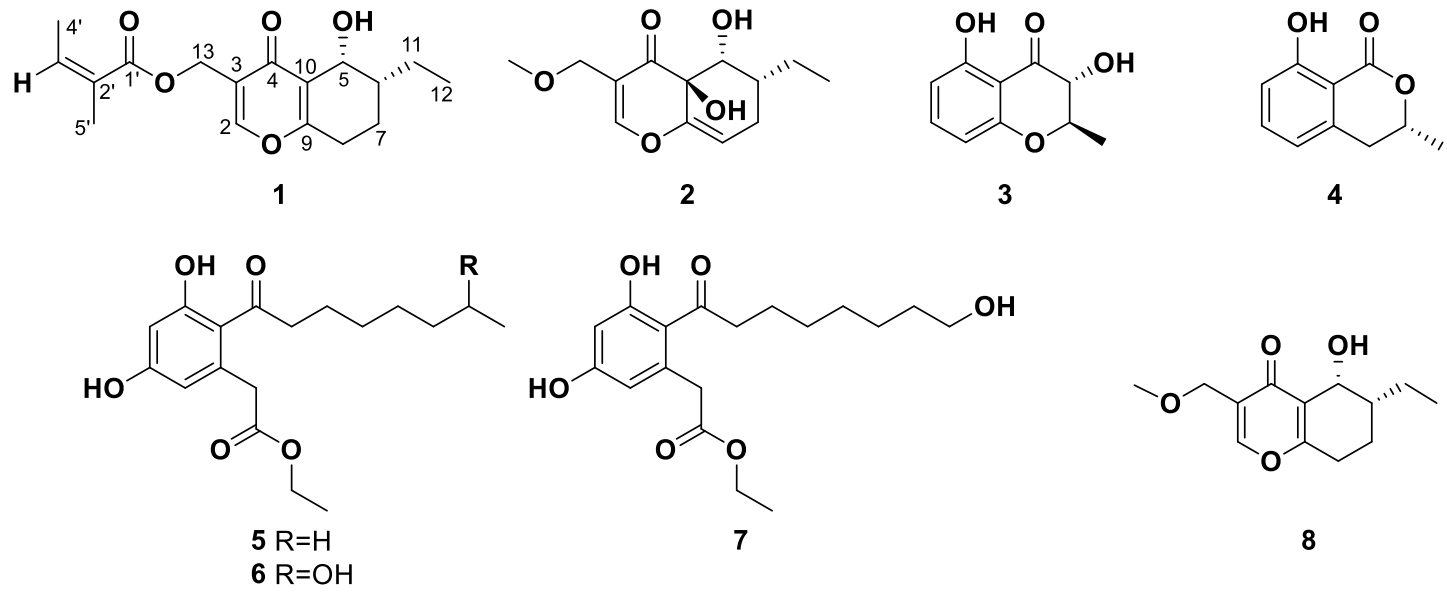

Figure 1. Chemical structures of compounds 1-8

2.4. Spectral Data of 13-angeloyloxy-diplosporin (1): White amorphous powder, $[\alpha]_{\mathrm{D}}^{25}=+50.0(\mathrm{c} 0.1$, $\mathrm{CH}_{3} \mathrm{OH}$ ); HRESIMS: $m / z$ 307.1534 $[\mathrm{M}+\mathrm{H}]^{+}\left(\right.$calcd 307.1545 for $\left.\mathrm{C}_{17} \mathrm{H}_{23} \mathrm{O}_{5}\right)$; for ${ }^{1} \mathrm{H}$ and ${ }^{13} \mathrm{C} \mathrm{NMR}$ data see Table 1 and Figures S3-S16.

\subsection{Determination of Pancreatic Lipase Inhibition}

The pancreatic lipase inhibition activity assay was conducted as previously [15]. P-nitrophenyl laurate was used as substrate. Porcine pancreatic lipase (Kayon-Shanghai, China) solution (150 $\mathrm{mg} / \mathrm{mL}$ ) was first centrifuged at $10,000 \mathrm{~g}$ at $4{ }^{\circ} \mathrm{C}$ for $5 \mathrm{~min}$ to obtain the supernatant enzyme. The substrate solution consisted of p-nitrophenyl laurate dissolved in $5 \mathrm{mM}(\mathrm{pH} 5.0)$ sodium acetate (1:100 $\mathrm{m} / \mathrm{v})$, as well as Triton X-100 (1:100 v/v). The substrate solution was placed in boiling water for $2 \mathrm{~min}$ to fully dissolve the reaction substrate. The sample is dissolved in 50\% DMSO solution.

The control consisted of $400 \mu \mathrm{l}$ of Tris buffer, $350 \mu \mathrm{l}$ of prepared reaction substrate solution, 100 $\mu \mathrm{l}$ of $50 \%$ DMSO solution, and $150 \mu \mathrm{l}$ of enzyme. The treatment samples consisted of $400 \mu \mathrm{L}$ of Tris buffer, $350 \mu \mathrm{L}$ of prepared reaction substrate solution, $100 \mu \mathrm{L}$ of sample solution, and $150 \mu \mathrm{L}$ of enzyme. A blank was needed for each group. The last step involved the incubation of the entire reaction mixture at $37^{\circ} \mathrm{C}$ for $2 \mathrm{~h}$ followed by centrifugation at $10,000 \mathrm{~g}$ for $3 \mathrm{~min}$. The absorbance (OD) of the reaction mixture was measured at $400 \mathrm{~nm}$ by using a SpectraMax M5 microplate reader and the inhibition of pancreatic lipase activity $(\%)$ was determined as follows: $\left(\mathrm{OD}_{\text {control- }}\right.$ $\mathrm{OD}_{\text {sample }} / \mathrm{OD}_{\text {control }} \times 100 \%$. The pancreatic lipase inhibitory activity was expressed as microgram of Orlistat equivalents ( $\mu \mathrm{g}$ Orlistat/g extract).

\section{Results and Discussion}

\subsection{Structure Elucidation}

Compound 1, obtained as a white, amorphous powder, gave the molecular formula of $\mathrm{C}_{17} \mathrm{H}_{22} \mathrm{O}_{5}$ from its HRESIMS (calcd for $[\mathrm{M}+\mathrm{H}]^{+}$307.1545, found 307.1534), indicating seven degrees of unsaturation.

The ${ }^{13} \mathrm{C}$ NMR and DEPT spectra of 1 displayed 17 carbon signals corresponding to three methyls, four methylenes (of which one was oxygenated), four methines (including one oxygenated and two olefinic carbon), and six quaternary carbons (including one keto carbonyl group, one ester carbonyl carbon, and four olefinic carbons) (Figure S3 and S4). This was consistent with a skeleton of a diplosporin polyketide. The carbon resonances at $\delta_{\mathrm{C}} 169.0,128.8,139.7,16.0$, and 20.7 revealed the presence of one angeloyloxy group, which is quite similar to the data of angeloyloxy group at 9angeloyloxythymol at $\delta_{\mathrm{C}} 168.9,126.9,138.9,15.8$, and 20.5 [16]. Comparison of its NMR data (Table 1) with those of 13-O-methyl-diplosporin (8) [17] revealed similarities except for the lack of the signal 
of a methoxy group in $\mathbf{8}$ instead of an angeloyloxy group $\left(\delta_{\mathrm{C}} 169.0,128.8,139.7,16.0\right.$, and 20.7) in $\mathbf{1}$ at $\mathrm{C}-13$, which was supported by the $\mathrm{HMBC}$ correlations from $\mathrm{H}_{2}-13\left(\delta_{\mathrm{H}} 4.97, \mathrm{~s}, 2 \mathrm{H}\right)$ to $\mathrm{C}-2, \mathrm{C}-3$, C4 , and C-1', from $\mathrm{H}-3^{\prime}\left(\delta_{\mathrm{H}} 6.13, \mathrm{~m}, 1 \mathrm{H}\right)$ to $\mathrm{C}-1^{\prime}, \mathrm{C}-4{ }^{\prime}$, and C-5', and from $\mathrm{H}_{3}-4^{\prime}\left(\delta_{\mathrm{H}} 1.94\right.$, ddd, $J=7.3$, $3.0,1.4 \mathrm{~Hz}, 3 \mathrm{H})$ and $\mathrm{H}_{3}-5^{\prime}\left(\delta_{\mathrm{H}} 1.86, \mathrm{dd}, J=3.0,1.5 \mathrm{~Hz}, 3 \mathrm{H}\right)$ to $\mathrm{C}-1^{\prime}, \mathrm{C}-2$ ', and C-3'. In addition, the HMBC spectrum of 1 showed correlations from one of $\mathrm{H}-2\left(\delta_{\mathrm{H}} 8.13, \mathrm{~s}, 1 \mathrm{H}\right)$, to C-3, C-4, C-9, and C13 , from $\mathrm{H}-5\left(\delta_{\mathrm{H}} 4.82, \mathrm{~d}, J=2.0 \mathrm{~Hz}, 1 \mathrm{H}\right)$, to C-4, C-6, C-7, C-9, and C-10, and from $\mathrm{H}_{2}-8\left(\delta_{\mathrm{H}} 2.66, \mathrm{~m}\right.$, $2 \mathrm{H})$ to $\mathrm{C}-5, \mathrm{C}-6, \mathrm{C}-7, \mathrm{C}-9$, and C-10. Furthermore, $\mathrm{H}_{2}-7\left(\delta_{\mathrm{H}} 1.73, \mathrm{~m}, 2 \mathrm{H}\right)$ showed HMBC correlations to $\mathrm{C}-5, \mathrm{C}-6, \mathrm{C}-8$, and C-9. Other correlations were H-6 $\left(\delta_{\mathrm{H}} 1.38\right.$, m, overlap, $\left.1 \mathrm{H}\right)$ with $\mathrm{C}-5, \mathrm{C}-7, \mathrm{C}-11$, and $\mathrm{C}-12, \mathrm{H}-11 \mathrm{a}\left(\delta_{\mathrm{H}} 1.40, \mathrm{~m}\right.$, overlap, $\left.1 \mathrm{H}\right)$ and $\mathrm{H}-11 \mathrm{~b}\left(\delta_{\mathrm{H}} 1.63, \mathrm{~m}, 1 \mathrm{H}\right)$ with $\mathrm{C}-5, \mathrm{C}-6, \mathrm{C}-7$, and $\mathrm{C}-12$, and $\mathrm{H}_{3}-12\left(\delta_{\mathrm{H}} 1.02, \mathrm{t}, J=7.3 \mathrm{~Hz}, 3 \mathrm{H}\right)$ with $\mathrm{C}-6$ and $\mathrm{C}-11$. These observed HMBC correlations, coupled with a spin system $\left(\mathrm{CHCH}\left(\mathrm{CH}_{3} \mathrm{CH}_{2}\right) \mathrm{CH}_{2} \mathrm{CH}_{2}, \mathrm{H}-5 / \mathrm{H}-6 /\left(\mathrm{H}_{2}-11 / \mathrm{H}_{3}-12\right) / \mathrm{H}_{2}-7 / \mathrm{H}_{2}-8\right)$ determined by ${ }^{1} \mathrm{H}^{-1} \mathrm{H}$ COSY and HSQC data, established the gross structure of $\mathbf{1}$. The HRESIMS (Figure $\mathrm{S} 1$ and Figure S2) data at $\mathrm{m} / z=207.1017\left(\mathrm{C}_{12} \mathrm{H}_{15} \mathrm{O}_{3}, \mathrm{M}\right.$-angeloyloxy group- $\left.\mathrm{H}_{2} \mathrm{O}+\mathrm{H}\right), 289.1429\left(\mathrm{C}_{17} \mathrm{H}_{21} \mathrm{O}_{4}, \mathrm{M}\right.$ $\left.-\mathrm{H}_{2} \mathrm{O}+\mathrm{H}\right), 307.1534\left(\mathrm{C}_{17} \mathrm{H}_{23} \mathrm{O}_{5}, \mathrm{M}+\mathrm{H}\right)$, and $329.2353\left(\mathrm{C}_{17} \mathrm{H}_{22} \mathrm{O}_{5} \mathrm{Na}, \mathrm{M}+\mathrm{Na}\right)$ also supported the structure of 1. In the ROESY spectrum (Figure S16) of 1, correlations of H-5 with H-6 showed that H5 and $\mathrm{H}-6$ in $\mathbf{1}$ had $\beta$-configurations. Therefore, $\mathbf{1}$ is named as 13-angeloyloxy-diplosporin.

The structures of 2-7 were elucidated by comparison of their 1D NMR data with literatures and named as 3-methoxymethyl-agistatine D (2) [17], (-)-gynuraone (3) [18], mellein (4) [19], cytosporone B (5) [20], dothiorelone A (6) [21], and dothiorelone C (7) [21].

Table 1. NMR data of compound $1\left({ }^{1} \mathrm{H}\right.$ NMR: $800 \mathrm{MHz},{ }^{13} \mathrm{C}$ NMR: $200 \mathrm{MHz}, \delta$ in ppm, $J$ in $\mathrm{Hz}$, recorded in methanol- $d_{4}$ )

\begin{tabular}{|c|c|c|c|c|c|}
\hline Positin & $\delta_{\mathrm{C}}(\mathbf{p p m})$ & $\delta_{H}(\mathbf{p p m})$ & НMBC & ${ }^{1} \mathrm{H}-{ }^{1} \mathrm{H}$ COSY & ROESY \\
\hline 2 & $156.7(\mathrm{CH})$ & $8.13 \mathrm{~s}$ & $3,4,9,13$ & - & $\mathrm{H}_{2}-13$ \\
\hline 3 & $124.4(\mathrm{C})$ & - & - & - & - \\
\hline 4 & $178.8(\mathrm{C})$ & - & - & - & - \\
\hline 5 & $62.2(\mathrm{CH})$ & $4.82(\mathrm{~d}, J=2.0)$ & $4,6,7,9,10$ & $\mathrm{H}-6$ & $\mathrm{H}-6, \mathrm{H}-11 \mathrm{~b}, \mathrm{H}_{3}-12$ \\
\hline 6 & $41.9(\mathrm{CH})$ & 1.38 overlap & $5,7,11,12$ & $\mathrm{H}-5, \mathrm{H}_{2}-7$ & $\mathrm{H}-5$ \\
\hline 7 & $22.6\left(\mathrm{CH}_{2}\right)$ & $1.73 \mathrm{~m}$ & $5,6,8,9$ & $\mathrm{H}-6, \mathrm{H}_{2}-8$ & $\mathrm{H}_{2}-8, \mathrm{H}_{3}-12$ \\
\hline 8 & $28.7\left(\mathrm{CH}_{2}\right)$ & $2.66 \mathrm{~m}$ & $5,6,7,9,10$ & $\mathrm{H}_{2}-7$ & $\mathrm{H}_{2}-7$ \\
\hline 9 & $169.0(\mathrm{C})$ & - & - & - & - \\
\hline 10 & $125.5(\mathrm{C})$ & - & - & - & - \\
\hline \multirow[t]{2}{*}{11} & $25.3\left(\mathrm{CH}_{2}\right)$ & 1.40a overlap & $5,6,7,12$ & $\mathrm{H}-11 \mathrm{~b}, \mathrm{H}_{3}-12$ & \\
\hline & & $1.63 \mathrm{~b} \mathrm{~m}$ & $5,6,7,12$ & $\mathrm{H}-11 \mathrm{a}, \mathrm{H}_{3}-12$ & $\mathrm{H}-5, \mathrm{H}_{3}-12$ \\
\hline 12 & $11.9\left(\mathrm{CH}_{3}\right)$ & $1.02(\mathrm{t}, J=7.3)$ & 6,11 & H-11a, H-11b & $\mathrm{H}-5, \mathrm{H}_{2}-7, \mathrm{H}-11 \mathrm{~b}$ \\
\hline 13 & $58.8\left(\mathrm{CH}_{2}\right)$ & $4.97 \mathrm{~s}$ & $1^{\prime}, 2,3,4$ & - & $\mathrm{H}-2$ \\
\hline $1^{\prime}$ & $169.0(\mathrm{C})$ & - & - & - & - \\
\hline $2^{\prime}$ & $128.8(\mathrm{C})$ & - & - & - & - \\
\hline $3^{\prime}$ & $139.7(\mathrm{CH})$ & $6.13 \mathrm{~m}$ & $1^{\prime}, 4^{\prime}, 5^{\prime}$ & $\mathrm{H}_{3}-4^{\prime}$ & $\mathrm{H}_{3}-4^{\prime}, \mathrm{H}_{3}-5^{\prime}$ \\
\hline $4^{\prime}$ & $16.0\left(\mathrm{CH}_{3}\right)$ & $\begin{array}{l}1.94(\mathrm{ddd}, J= \\
7.3,3.0,1.4)\end{array}$ & $1^{\prime}, 2^{\prime}, 3^{\prime}$ & H-3' & $\mathrm{H}-3^{\prime}$ \\
\hline $5^{\prime}$ & $20.7\left(\mathrm{CH}_{3}\right)$ & $\begin{array}{l}1.86(\mathrm{dd}, J= \\
3.0,1.5)\end{array}$ & $1^{\prime}, 2^{\prime}, 3^{\prime}$ & - & H-3' \\
\hline
\end{tabular}

\subsection{Pancreatic Lipase Inhibition Activity}

All isolated compounds were tested for lipase inhibited activity, compounds cytosporone B (5) and dothiorelone A (6) strongly inhibited lipase activities compared to the positive control (Orlistat, $\mathrm{IC}_{50}=43 \mu \mathrm{g} / \mathrm{mL}$ ) with the $\mathrm{IC}_{50}$ values at 115 and $275 \mu \mathrm{g} / \mathrm{mL}$, respectively. 


\section{Acknowledgments}

This project was supported financially by the National Natural Science Foundation of China (Nos. 31760096, 81660717, and 81860624); Yunnan Ten-thousand Talents Program (W.-G., Wang); Yunnan Innovative Research Team for Discovery and Comprehensive Utilization of Functional Small Molecules in Medicinal Plants, and the Science Foundation of Yunnan, the National Natural Science Foundation of Yunnan provinces (Nos. 2017FB133, 2017FD121, and W.-G., Wang).

\section{Supporting Information}

Supporting information accompanies this paper on http://www.acgpubs.org/journal/records-ofnatural-products

\section{ORCID}

Shan-Ling Sheng: 0000-0002-4615-3315

Yan-Ping Li: 0000-0002-2409-3569

Hai-Ying Xiang: 0000-0001-8308-5481

Yun-Liu: 0000-0003-1334-2862

Yu-Dan Wang: 0000-0001-8072-7944

Ling-Peng Kong: 0000-0001-8549-2849

Gang-Du: 0000-0001-7706-8589

Qiu-Fen Hu: 0000-0003-4721-9248

Yi-Jian Chen: 0000-0002-2555-6668

Wei-Guang Wang: 0000-0003-3395-767X

\section{References}

[1] T. Hautbergue, E. L. Jamin, L. Debrauwer, O. Puel and I. P. Oswald (2018). From genomics to metabolomics, moving toward an integrated strategy for the discovery of fungal secondary metabolites, Nat. Prod. Rep. 35, 147-173.

[2] H. Jiang, W. J. Man, A. J. Hou, L. Yang, X. D. Xing, M. L. Yan, X. Y. Guo and L. Yang (2018). The chemical constituents from the active fractions of Eleutherine bulbosa with their antimicrobial activity, Nat. Prod. Res. 1-7. https://doi.org/10.1080/14786419.2018.1530229

[3] R. N. Kharwar, A. Mishra, S. K. Gond, A. Stierle and D. Stierle (2011). Anticancer compounds derived from fungal endophytes: their importance and future challenges, Nat. Prod. Rep. 28, 1208-1228.

[4] S. Krishnamurthy, K. N. Murthy and S. Thirumale (2018). Characterization of Ankaflavin from Penicillium aculeatum and its cytotoxic properties, Nat. Prod. Res. 1-6. https://doi.org/10.1080/14786419.2018.1522633

[5] Zulqarnain, Z. Iqbal, R. Cox, J. Anwar, N. Ahmad, K. Khan, M. Iqbal, N. Manzoor and S. U. Khattak (2018). Antifungal activity of compounds isolated from Aspergillus niger and their molecular docking studies with tomatinase, Nat. Prod. Res. 1-5. https://doi.org/10.1080/14786419.2018.1548447

[6] G. L. Challis (2008). Genome mining for novel natural product discovery, J. Med. Chem. 51, 26182628.

[7] J. Yaegashi, B. R. Oakley and C. C. Wang (2014). Recent advances in genome mining of secondary metabolite biosynthetic gene clusters and the development of heterologous expression systems in Aspergillus nidulans, J. Ind. Microbiol. Biotechnol. 41, 433-442.

[8] T. Asai, T. Taniguchi, T. Yamamoto, K. Monde and Y. Oshima (2013). Structures of Spiroindicumides A and $\mathrm{B}$, unprecedented carbon skeletal spirolactones, and determination of the absolute configuration by vibrational circular dichroism exciton approach, Org. Lett. 15, 4320-4323.

[9] R. H. Cichewicz (2010). Epigenome manipulation as a pathway to new natural product scaffolds and their congeners, Nat. Prod. Rep. 27, 11-22. 
[10] X. Wang, J. G. Sena Filho, A. R. Hoover, J. B. King, T. K. Ellis, D. R. Powell and R. H. Cichewicz (2010) Chemical epigenetics alters the secondary metabolite composition of guttate excreted by an atlantic-forest-soil-derived Penicillium citreonigrum, J. Nat. Prod. 73, 942-948.

[11] J. X. Zhu, L. J. Ding and S. He (2018). Discovery of a new biphenyl derivative by epigenetic manipulation of marine-derived fungus Aspergillus versicolor, Nat. Prod. Res. 1-5.

[12] W. G. Wang, A. Li, B. C. Yan, S. B. Niu, J. W. Tang, X. N. Li, X. Du, G. L. Challis, Y. S. Che, H. D. Sun and J. X. Pu (2016). LC-MS-guided isolation of Penicilfuranone A: a new antifibrotic furancarboxylic acid from the plant endophytic fungus Penicillium sp. sh18, J. Nat. Prod. 79, 149-155.

[13] W. G. Wang, L. Q. Du, S. S. Sheng, A. Li, Y. P. Li, G. G. Cheng, G. P. Li, G. L. Sun, Q. F. Hu and Y. Matsuda (2019). Genome mining for fungal polyketide-diterpenoid hybrids: discovery of key terpene cyclases and multifunctional P450s for structural diversification, Org. Chem. Front. 6, 571-578.

[14] B. C. Yan, W. G. Wang, D. B. Hu, X. Sun, L. M. Kong, X. N. Li, X. Du, S. H. Luo, Y. Liu, Y. Li, H. D. Sun and J. X. Pu (2016). Phomopchalasins A and B, two cytochalasans with polycyclic-fused skeletons from the endophytic fungus Phomopsis sp. shj2, Org. Lett. 18, 1108-1111.

[15] C. T. Zhang, Y. L. Ma, F. D. Gao, Y. X. Zhao, S. B. Cai and M. J. Pang (2018). The free, esterified, and insoluble-bound phenolic profiles of Rhus chinensis mill. fruits and their pancreatic lipase inhibitory activities with molecular docking analysis, J. Funct. Foods 40, 729-735.

[16] Y. L. Wang, J. M. Li, H. Wang, D. Q. Jin, H. Q. Chen, J. Xu, Y. Ohizumi and Y. Q. Guo (2014). Thymol derivatives from Eupatorium fortunei and their inhibitory activities on LPS-induced NO production, Phytochemistry Lett. 7, 190-193.

[17] A. Ibrahim, D. Sørensen, H. A. Jenkins, B. E. McCarry and M. W. Sumarah (2014). New diplosporin and agistatine derivatives produced by the fungal endophyte Xylaria sp. isolated from Vitis labrusca, Phytochemistry Lett. 9, 179-183.

[18] W. Y. Lin, Y. H. Kuo, Y. L. Chang, C. M. Teng, E. C. Wang, T. Ishikawa and I. S. Chen (2003). Antiplatelet aggregation and chemical constituents from the rhizome of Gynura japonica, Planta Med. 69, 757-764.

[19] B. Kalinova, J. Kindl, P. Jiros, P. Zacek, S. Vasickova, M. Budesinsky and I. Valterova (2009). Composition and electrophysiological activity of constituents identified in male wing gland secretion of the bumblebee parasite Aphomia sociella, J. Nat. Prod. 72, 8-13

[20] J. Beau, N. Mahid, W. N. Burda, L. Harrington, L. N. Shaw, T. Mutka, D. E. Kyle, B. Barisic, A. V. Olphen and B. J. Baker (2012). Epigenetic tailoring for the production of anti-infective cytosporones from the marine fungus Leucostoma persoonii, Mar. Drugs 10, 762-774.

[21] Q. W. Tan, P. H. Fang, J. C. Ni, F. L. Gao and Q. J. Chen (2017). Metabolites produced by an endophytic Phomopsis sp. and their anti-TMV activity, Molecules 22, 2073.

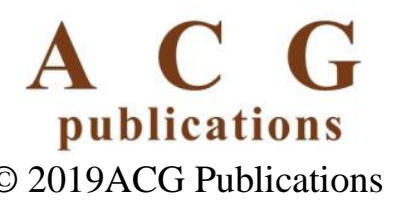

